\title{
MAKNA FILOSOFI TARI PERSEMBAHAN DAN KAITANNYA TERHADAP KARAKTER MASYARAKAT KOTA PEKANBARU PROVINSI RIAU
}

\author{
Fatia Kurniati dan Kuswarsantyo \\ Program Pascasarjana, Universitas Negeri Yogyakarta \\ E-mail: fatiaku4@gmail.com,condrowasesa@yahoo.co.id
}

\begin{abstract}
Abstrak
Penelitian ini bertujuan: (1) untuk mengetahui filosofi dari Tari Persembahan, (2) untuk mengetahui relevansi makna filosofi Tari Persembahan terhadap karakter masyarakat Kota Pekanbaru Provinsi Riau. Jenis penelitian ini adalah kualitatif, dengan teknik pengumpulan data yang digunakan yaitu observasi non partisipan, wawancara, dan dokumentasi, serta teknik analisis yang digunakan yaitu reduksi data, display data, dan verifikasi data. Hasil penelitian ini menjelaskan bahwa makna filosofi yang terkandung dalam Tari Persembahan berasal dari adab sopan santun yang dimiliki masyarakat Melayu yang termasuk dalam filosofi masyarakat Melayu yaitu Adat Bersendikan Syarak Syarak Bersendikan Kitabullah, yang didapati dalam gerak tari, kostum tari, properti tari, dan juga proses latihan. Sedangkan gerak-gerak yang ada dalam Tari Persembahan berasal dari tradisi menjunjung duli dan kemudian dikembangkan menjadi ragamragam gerak baru. Relevansi antara makna filosofi Tari Persembahan dan karakter masyarakat Kota Pekanbaru Provinsi Riau adalah dalam hal filosofinya, yaitu makna dari Tari Persembahan merupakan adab sopan santu masyarakat Melayu yang juga terkandung dalam filosofi masyarakat Melayu yang mendiami Kota Pekanbaru Provinsi Riau.
\end{abstract}

Kata kunci: Tari Persembahan, makna filosofi, nilai karakter

\section{THE PHILOSOPHY OF PERSEMBAHAN DANCE AND THE CONNECTION WITH PEOPLE CHARACTERISTICS IN PEKANBARU CITY OF RIAU PROVINCE}

\begin{abstract}
This research aims: (1) to know the philosophy of Persembahan Dance, (2) to know the connection of it with Persembahan Dance in people characteristics in Pekanbaru of Riau Province. The type of research is qualitative, and the data collection technique are non participant observation, interview, and documentation. The data were analyzed by data reduction, data display, and data verification. The results showed, the philosophy of the Persembahan dance derived from courtesy of respect that belongs to the Malay poeple which is included in the philosophy of the Malay society, namely Adat Bersendikan Syarak Syarak Bersendikan Kitabullah, which is found in the movement of the dance, dance costume, dance property, and also exercise process. While the dance movements that exist in the Persembahan Dance comes from the tradition of menjunjung $d u l i$ and then developed into a variety of new motions. The relevance between the philosophy of Persembahan Dance and the people characteristics of Pekanbaru city of Riau Province is that the meaning of Persembahan Dance is courtesy of Malay community also embodied in the philosophy of Malay people who inhabit Pekanbaru city of Riau Province. The philosophy is then renovated in the form of character value, the value of respect, the value of appreciating, the value of hard work, the value of teamwork, the value of discipline, the value of friendship, and the value of patriotism.
\end{abstract}

Keywords: Persembahan Dance, philosophy meaning, character value 


\section{PENDAHULUAN}

Kehidupan masyarakat Indonesia tidak lepas dari kesenian dan kebudayaannya yang khas. Kesenian dan kebudayaan tersebut berasal dari setiap daerah yang ada di Indonesia. Indonesia merupakan negara yang mempunyai beragam suku, dan setiap daerah dari suku tersebut, terdapat kesenian dan budaya yang berbeda pula. Kesenian dan kebudayaan tersebut hadir dari interaksi maupun filosofi hidup masyarakatnya. Lebih-lebih sebuah kesenian, biasa berangkat dari kegiatan dan pola hidup sehari-hari masyarakat itu sendiri. Semakin majunya zaman, kesenian hadir sudah lebih mengutamakan bentuk estetikanya baik dari segi gerak, kostum maupun penyajiannya. Namun juga tidak dipungkiri bahwa selain bentuk dari nilai estetika yang hadir pada sebuah karya seni, lebih dalam lagi akan dapat menemukan sebuah makna filosofi yang terkandung didalamnya. Makna filosofi tersebut bisa berasal dari kehidupan masyarakat, tradisi, maupun adat istiadat masyarakat tempat kesenian tersebut lahir.

Seperti halnya masyarakat Kota Pekanbaru Provinsi Riauyang didominasimasyarakat Suku Melayu. Maka kesenian yang ada didalamnya pun tidak lepas dari pengaruh nilai-nilai ke Melayuan yang dimiliki masyarakatnya. Nilainilai dalam masyarakat Melayu juga tidak lepas dari ajaran agama Islam yang telah ada sejak zaman kerajaan Siak. Oleh karena itu masyarakat Melayu juga kebanyakan beragama Islam. Ajaran agama ini menjadi landasan dalam filosofi masyarakat Melayu itu sendiri, yang berbunyi Adat Bersendikan Syarak Syarak Bersendikan Kitabullah, yang artinya adat istiadatnya berlandaskan pada ajaran agama dan kitab Allah. Hal-hal ini beriring sejalan dengan adat masyarakat Melayu, termasuk dalam hal kesenian. Adat, adab dan tradisi tersebut juga ikut mempengaruhinya, contohnya dalam seni tari.

\section{Makna Filosofi}

Sebuah kesenian tidak hanya bertujuan sebagai media hiburan semata, namun kesenian yang terdapat pada setiap daerah memiliki kekhasannya masing-masing, baik kekhasan mengenai gerak, kostum, iringan musik maupun bentuk penyajiannya. Kesenian tidak hanya terpaku pada nilai estetika saja, namun jika lebih dalam lagi untuk dipahami, sebuah kesenian juga memiliki makna filosofi yang berkaitan erat dengan kebudayan masyarakat pemiliknya. Menurut Carroll (1999) dalam bukunya yang berjudul Philosophy of Art: A Contemporary Introduction, bahwa filosofi adalah "the usually meaning something like their deepest and most abiding beliefs". Filosofi menurut Carroll adalah suatu hal yang mendalam dan diyakini oleh seseorang atau kelompok masyarakat. Sedangkan menurut Herusatoto dalam Luvia (2008) menjelaskan bahwa filosofi berangkat dari istilah filsafat yang mempunya arti berpikir dengan menggunakan akal budi sedalam-dalamnya dengan penuh tanggung jawab, mengikuti metode dan sistem yang teratur, yang tertib untuk mengungkapkan misteri permasalahan yang ingin kita pecahkan, setelah itu dicari kesimpulan yang umum dan universal.

Beberapa pendapat mengenai definisi filosofi yang telah dijelaskan terdapat kesamaan yang bisa menjadi kesimpulan pendapat diatas bahwa filosofi adalah proses atau cara berpikir yang diyakini seseorang dan kelompok yang digunakan untuk mengatasi permasalahan yang dimiliki. Buah dari pikiran tersebut yang menjadi keyakinan dalam suatu masyarakat. Begitu pula dengan masyarakat Melayu yang mempunyai filosofi yang berlandaskan pada adat dan juga ajaran agama, yang ikut mempengaruhi kesenian yang mereka miliki. Dengan kata lain suatu kesenian tidak lepas dari pengaruh filosofi dari kebudayaan masyarakatnya. Namun pada saat ini hal tersebut kurang dipahami dan kurang menjadi perhatian, karena pada kenyataanya sebuah kesenian dapat menjadi identitas dari kebudayaan masyarakat itu sendiri di hadapan masyarakat luar.

Selain makna filosofi yang terdapat dalam suatu masyarakat yang juga ikut mempengaruhi kesenian masyarakat tersebut dan nilai estetika yang dimilikinya, jauh dari pada itu sebuah 
kesenian bisa menjadi media diajarkan dan ditanamkan nilai karakternya pada anak-anak Salah satu contohnya adalah seni tari, seperti yang diungkapkan oleh Suparjo (2015) dalam pelajaran seni tari tersebut siswa dapat diajarkan nilai karakter seperti taat aturan, disiplin, daya juang, kepekaan dan sebagainya. Melalui pendapat Suparjo tersebut dapat disimpulkan bahwa tidak hanya mata pelajaran yang umunya berkaitan langsung pada interaksi sosial seperti kewarganegaraan atau mata pelajaran agama saja, namun melalui mata pelajaran seni budaya juga dapat mejadi media menanamkan nilai karakter kepada siswa.

\section{Tari Persembahan}

Tari merupakan seni yang hampir bisa ditemukan diberbagai daerah bahkan negara sekalipun. Dari sejarah hadirnya tari tersebut, menurut Royce (2007) tari merupakan kesenian yang tertua dari kesenian lainnya. Masih menurut Royce (2007) tari adalah hasil pola gerak tubuh dalam ruang dan waktu. Sedangkan menurut Sedyawati dalam Jurnal Ratnaningrum (2011) menjelaskan bahwa tari adalah bentuk upaya untuk mewujudkan keindahan susunan gerak dan irama yang dibentuk dalam satuansatuan komposisi. Dari beberapa pendapat tersebut dapat disetujui bahwa tari hasil adalah dari gerak tubuh, gerak yang indah dan juga tersusun dalam sebuah komposisi tari.

Keindahan dari sebuah tari tidak hanya berasal dari gerak aja, namun dapat pula berasal dari elemen-elemen lainnya seperti kostum, properti dan iringan musiknya. Keindahan tersebut juga tidak lepas dari kekhasan kebudayaan masyarakatnya yang memiliki tradisi-tradisi, adab baik dan berbusana maupun bermasyarakat yang didukung pula oleh filosofi yang dimilikinya. Seperti yang dijelaskan oleh Sedyawati (1986) bahwa tari tidak hanya sekedar gerak-gerak yang mempunyai pola dan keindahan sendiri, namun juga mencerminkan kebudayaan suatu daerah. Sedangkan menurut Hadi (2005) tarian yang hidup dan berkembang di masyarakat, akan memberi manfaat dan menggambarkan karakter dari masyarakat setempat dikaitkan sesuai dengan ciri khas budaya tari tersebut berasal yang memiliki keindahannya masingmasing, yang mempunyai gerakan yang ritmis dan indah yang berasal dari suatu kebudayaa daerah.

Seperti contohnya Tari Persembahan yang berasal dari daerah Riau. Tari Persembahan merupakan tari penyambutan masyarakat Melayu Riau yang bertujuan untuk menerima tamu kehormatan. Tari Persembahan identik dengan budaya Melayu, baik dari segi kostum, gerak, dan juga musik iringannya. Adapun bentuk kostum Tari Persembahan dapat dilihat pada gambar berikut:

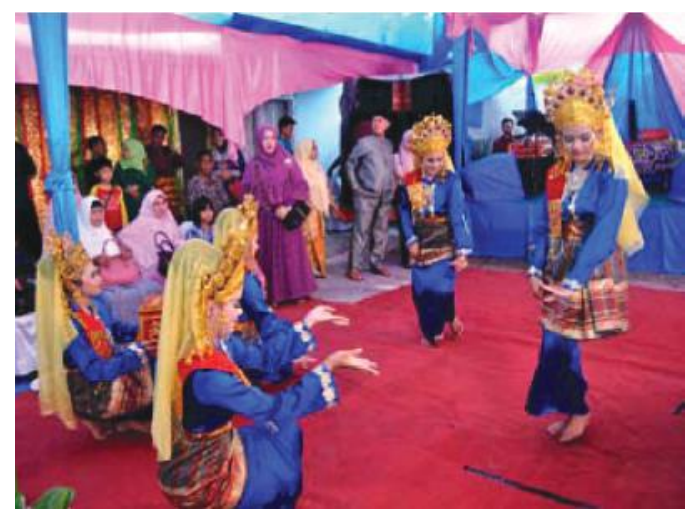

Gambar 1. Kostum Tari Persembahan (Dokumentasi Pribadi, 2017)

Gambar tersebut memperlihatkan susunan penggunaan kostum penari Persembahan mulai dari bagian kepala hingga pakaian bawah sebagai berikut :

1. Selendang atau tudung manto

2. Sunting Melayu

3. Tekat

4. Jurai panjang

5. Baju kebaya laboh lengan panjang

6. Sebai (bahu kanan)

7. Bros (pada kancing baju bagian atas)

8. Kain samping atau songket (pada pinggang)

9. Bengkung (pada pinggang)

10. Rok panjang

11. Tidak menggunakan alas kaki

Kostum yang digunakan penari Persembahan berasal dari busana Melayu yang sopan dan tertutup. Seperti yang dijelaskan 
Mohd Rosli Saludin dalam Adilan dan Husin (2016) menjelaskan bahwa busana Melayu bertujuan untuk kesopanan dan beretika sesuai dengan adat Melayu dan tidak terbatas pada penggunaan kain dan baju saja, melainkan sebuah kelengkapan adat istiadat masyarakat untuk memenuhi kehidupan nilai, moral, dan keindahan budaya Melayu.

Selain kostum yang mencerminkan kebudayaan masyarakat Melayu, adapun musik pengiringnya juga menggunakan musik khas Melayu yang yang berasal dari suara beberapa alat musik seperti marwas, biola, gendang, gambus dan akordion. Sedangkan lagu yang biasa dibawakan pada Tari Persembahan adalah lagu Makan Sirih. Adapun sebait liriknya sebagai berikut:

"Selamat datang Tuan dan Puan,

Tepak pengasih dari Tuan Puteri,

Doa dan rakhmad kami persembahkan,

Semoga Tuan dan Puan senang dihati"

Setelah kostum dan musik iringan yang sarat akan kebudayaan masyarakat Melayu, properti yang digunakan dalam Tari Persembahan juga tidak lepas dari adat dan tradisi masyarakat Melayu itu sendiri, yaitu tepak sirih. Tepak sirih merupakan properti utama dan satusatunya dalam Tari Persembahan, nantinya tepak sirih tersebut akan dipersembahkan atau diberikan kepada tamu kehormatan pada akhir tarian. Adapun isi dari tepak siri tersebut antara lain menurut O.K. Nizami Jamil (2009) :

1. Daun sirih secukupnya tersusun rapi dalam keadaan tertelungkup dengan gagangnya mengarah ke atas.

2. Lima atau tiga bungkus sirih yang telah dikapur, siap untuk dijamah dan disantap.

3. Kapur sirih se-cembul

4. Gambir diracik se-cembul

5. Pinang diracik se-cembul

6. Tembakau se-cembul

7. Kacip sebuah

\section{Perubahan}

Dalam sebuah kebudayaan dan kesenian dapat terjadi perubahan yang dipengaruhi banyak faktor dan berdampak pada masyarakat maupun kebudayaan itu sendiri. Permasalahan tersebut akan di analisis dengan menggunakan teori perubahan dan perkembangan atau transit dan transition dari Svasek (Svasek, 2007). Svasek menjelaskan bahwa:

Transit records the location or movement of objects over time and across social or geographic boundaries, while transition analyses how the meaning, value and status of those objects, as well as how people experience them, is changed by that process.

Dari pendapat Svavek tersebut dapat disimpulkan bahwa transit lebih cenderung kepada proses perpindahan yang hingga melewati dari batas-batas sosialnya. Proses transisi cenderung pada proses perubahan nilai dan makna dari suatu karya seni yang dijadikan sebagai objeknya. Perubahan tersebut diperkuat dengan dari teori dari Hauser (1974) mengenai perubahan sosial. Hauser menjelaskan bahwa seni adalah produk sosial, sehingga adanya perubahan dalam dunia seni merupakan produk dari masyarakat yang berubah pula.

Perubahan-perubahan tersebut dapat terjadi karena ada faktor yang mempengaruhi. Menurut Kuswarsantyo (2008) faktor tersebut diakibatkan karena makin banyaknya warga pendatang dari daerah lain masuk ke wilayah budaya tertentu. Dinamika perkembangan budaya ini terjadi karena pola pemikiran masyarakat sudah semakin kritis, seiring dengan tingkat pendidikan yang makin tinggi, sehingga membuka peluang pengaruh itu terhadap perkembangan seni tradisional.

\section{Nilai Budaya dan Karakter Masyarakat Melayu}

Nilai menurut Alexander (2016) sendiri secara umum memiliki arti sifat-sifat atau hal-hal yang penting atau berharga bagi kemanusiaan Nilai-nilai budaya mempunyai pengertian sebagai berikut: nilai-nilai dalam hal ini mempunyai makna keistimewaan: apa yang dihargai, di nilai tinggi, atau dihargai sebagai suatu bentuk kebudayaan. Koentjaraningrat (2016) menyatakan bahwa sistem budaya yang 
paling berpengaruh terhadap kehidupan orang Melayu adalah agama dan adat istiadat agama Islam merupakan pengaruh utama dalam budaya Melayu bila dibandingkan dengan adat istiadat. Dalam terminologi adat, adat sebenar adat dan merupakan pegangan hidup orang Melayu adalah Al Quran, hadist, dan fiqih. Adat bersendikan syarak dan syarak bersendikan kitabullah.

Pada nilai yang berlaku dalam masyarakat Melayu tersebut yang juga mempengaruhi masyarakat Melayu dalam berkesenian. Begitu pula karakter masyarakatnya yang mengikuti pada adat yang berlandaskan pada ajaran agama. Hal ini yang menjadi faktor dalam pembuatan beberapa peraturan daerah (perda), contohnya dalam perda mengenai penggunaan busana Melayu di lingkungan pendidikan, pegawai negeri sipil, dan juga swasta atau badan usaha milik daerah.

\section{Nilai Karakter}

Pendidikan mempunyai tujuan untuk dapat membentuk karakter baik pada diri seseorang. Karakter menurut Tadkiratun Musfiroh dalam Gunawan (2014) menjelaskan bahwa mengacu kepada serangkaian sikap (attitude), perilaku (behaviour), motivasi (motivations), dan keterampilan (skills). Karakter dari bahasa Yunani berarti to mark atau menandai dan memfokuskan cara mengamplikasikan nilai kebaikan dalam bentuk tindakan atau tingkah laku. Dari definisi mengenai karakter yang telah dijelaskan, dapat dipahami bahwa karakter merupakan gambaran dari sikap dan perilaku serta watak yang dimiliki oleh seseorang, dapat dilihat melalui tindakan-tindakan yang dilakukan sehari-hari. Oleh karenanya pendidikan dan karakter pada saat ini sudah menjadi satu kesatuan untuk diajarkan baik pada siswa maupun di lingkungan keluarga dan masyarakat.

Adapun tujuan dari pendidikan karakter menurut Ramli dalam Gunawan (2014) memiliki esensi dan makna yang sama dengan pendidikan moral dan pendidikan akhlak, yaitu untuk membentuk pribadi anak supaya menjadi manusia, warga masyarakat, dan warga negara yang baik.

\section{METODE \\ Jenis Penelitian}

Penelitian ini menggunakan pendekatan kualitatif analisis deskriptif untuk mengetahui secara lebih mendalam mengenai makna filosofi Tari Persembahan dan relevansinya terhadap karakter masyarakat Kota Pekanbaru Provinsi Riau.

\section{Waktu dan Tempat Penelitian}

Waktu penelitian dimulai dari bulan Agustus 2016 hingga Januari 2017. Tempat penelitian ini dilaksanakan diantaranya yaitu di SMA Negeri 1 Pekanbaru, Sanggar Tari Malay Pekanbaru, dan lokasi pertunjukan Tari Persembahan.

\section{Subjek Penelitian}

Subjek dari penelitian ini masyarakat Kota Pekanbaru Provinsi Riau, yang terdiri dari satu orang koreografer Tari Persembahan, satu orang guru seni budaya, lima orang pelajar SMA, tiga orang penari Persembahan, dan satu orang pegawai tata usaha.

\section{Data dan Teknik Pengumpulan Data}

Data yang digunakan dalam penelitian ini terbagi dua yaitu data primer dan data sekunder. Data primer data yang diperoleh melalui serangkaian kegiatan seperti observasi di sanggar, sekolah, wawancara, dan dokumentasi. Sedangkan data sekunder merupakan data yang diperoleh melalui pengumpulan data yang berupa dokumentasi, berupa video Tari Persembahan, musik Tari Persembahan, fotofoto ragam gerak Tari Persembahan, foto kostum penari Tari Persembahan, foto tepak sirih, dan isinya, referensi-referensi (literatur, tulisan, buku, hasil penelitian, dan jurnal penelitian) yang berkaitan. Adapun teknik pengumpulan data yang digunakan yaitu observasi non partisipant, wawancara, dan dokumentasi. 


\section{Teknik Analisis Data}

Teknik analisis data yang digunakan dalam penelitian ini yaitu dari model analisis data Miles dan Huberman. Langkah-langkahnya sebagai berikut:

\section{a. Reduksi data}

Reduksi data merupakan proses pengumpulan data penelitian yang relevan dengan penelitian. Pada tahap ini mencatat dan mengumpulkan data-data mengenai Tari Persembahan dan karakter masyarakat Kota Pekanbaru Provinsi Riau. Proses reduksi data berlangsung selama penelitian di lapangan. Setelah data dapat dikumpulkan kemudian dipilih untuk dijadikan sebagai data yang selanjutnya digunakan dalam membuat kesimpulan dan verifikasi data.

\section{b. Display/penyajian data}

Pada tahap display atau penyajian data, keseluruhan data yang dikumpulkan tidak dapat seluruhnya digunakan oleh karena itu hal yang harus dilakukan dalam tahap ini adalah dapat menyusun terlebih dahulu data yang didapat secara sistematis, sehingga dapat menjawab permasalahan yang diteliti. Dalam tahap ini data yang berkaitan seputar makna filosofi Tari Persembahan dan karakter masyarakat Kota Pekanbaru Provinsi Riau disusun secara sistematis sehingga nantinya menjawab permasalahan dari penelitian ini.

\section{c. Kesimpulan/verifikasi data}

Pada tahap kesimpulan atau verifikasi data ini, dilakukan kegiatan lanjutan dari reduksi data dan display data. Dalam menentukan kesimpulan, dapat ditarik kesimpulan sementara tentang makna filosofi Tari Persembahan dan relevansinya terhadap karakter masyarakat Kota Pekanbaru Provinsi Riau, sementara itu dapat pula bertukar pikiran dengan sesama teman dan triangulasi, sehingga kesimpulan ilmiah dapat tercapai.

\section{HASIL DAN PEMBAHASAN}

Hasil penelitian ini dibagi menjadi dua sesuai dengan rumusan masalah yang ada dalam penelitian ini, yaitu:

\section{Makna Filosofi}

Makna filosofi yang terkandung dalam Tari Persembahan berasal dari adab sopan santun masyarakat Melayu. Selain adab sopan santun, terdapat juga adab malu yang merupakan hal yang dipegang betul oleh masyarakat Melayu. Adab-adab ini termasuk dalam karakter masyarakat Melayu, yaitu suku yang mendominasi daerah Kota Pekanbaru Provinsi Riau. Adab-adab ini berasal pada filosofi masyarakat Melayu yaitu Adat Bersendikan Syarak Syarak Bersendikan Kitabullah. Hadirnya filosofi ini melalui karakter dari masyarakat Melayu itu sendiri yang pada zaman kerajaan dahulu sudah mulai memeluk agama Islam. Maka ajaran ini yang menjadi landasan hidup masyarakat Melayu dan menjadi filosofi hidup mereka. Maksud dari filosofi tersebut adalah adat yang ada berdasarkan pada syariat agama, yaitu syariat agama berdasarkan dari kitab Allah. Jadi agama bagi masyarakat Melayu mempunyai kedudukan yang penting utamanya dalam peraturan adat.

Makna-makna tersebut dapat dilihat dari bentuk gerak, kostum dan properti serta proses latihan Tari Persembahan. Makna gerak dari Tari Persembahan berasal dari tradisi menjunjung duli. Tradisi ini biasa dilakukan masyarakat Melayu pada saat hari lebaran, yaitu bersilaturahmi kepada Raja sebagai bentuk rasa menghormati dan menghargai. Dari tradisi ini muncul ragam-ragam baru dalam gerak Tari Persembahan, seperti gerak sembah atau salam yang mencerminkan dari tradisi menjunjung duli yaitu menghormati Raja, yang mempunyai relevansi pada bentuk nilai menghormati dan menghargai dalam Tari Persembahan.

Gerak ini bertujuan untuk menghormati tamu yand hadir dalam sebuah acara. Gerak sembah atau salam ini dilakukan pada awal tarian sebagai bentuk menghormati dan mengahargai tamu. adapun gambar gerakan sembah atau salam sebagai berikut: 


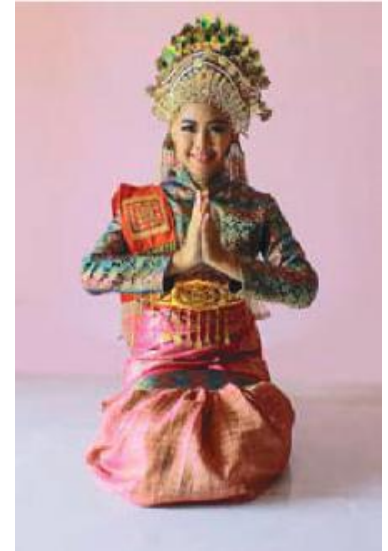

Gambar 2. Gerak Sembah atau Salam (Dokumentasi Pribadi, 2017)

Gerak lenggang patah sembilan, sebagai bentuk kelemah lembutan masyarakat Melayu dan juga ketegasan dalam berpikir dan bertindak pada saat mereka merasa terganggu. Adapun gerak lenggang patah sembilan dapat dilihat pada gambar berikut:

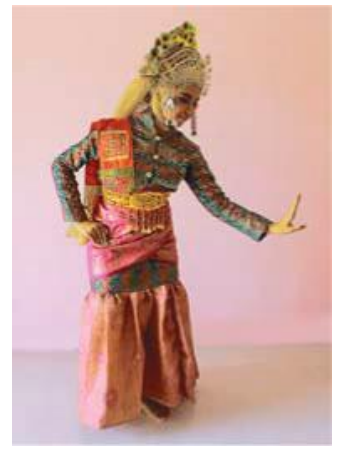

Gambar 3. Gerak Lenggang Patah Sembilan (Dokumentasi Pribadi, 2017)

Gerak selembayung yang mempunyai makna pengasih, kewibaan, keperkasaan, yang berasal dari makna selembayung sendiri. Selain itu gerak selembayung mencerminkan bentuk nilai dari karakter cinta tanah air, yaitu menunjukkan identitas gerak yang berasal dari kearifan lokal yang dimiliki. Dalam masyarakat Melayu selembayung mempunyai makna yaitu (1) Tajuk Bangunan: Selembayung membangkitkan seri dan cahaya bangunan; (2) Pekasih Bangunan: Lambang keserasian dalam bangunan; (3) Pasak Atap: lambang hidup yang tahu diri; (4) Tangga Dewa: lambang tempat turun para dewa, mambang, akuan, soko, keramat, dan sisi yang membawa keselamatan bagi manusia; (5) Rumah Beradat: tanda bahwa bangunan itu adalah tempat kediaman orang berbangsa, balai atau tempat orang patut-patut; (6) Tuah Rumah: yakni sebagai lambang bahwa bangunan itu mendatangkan tuah kepada pemilikinya; (7) Lambang keperkasaan dan wibawa; (8) Lambang kasih sayang (Faisal \& Wihardyanto, 2013). Selembayung merupakan bentuk ujung atap dari rumah adat masyarakat Melayu. Adapun selembayung yang ada pada ujung atap bangunan masyarakat Melayu dan bentuk gerak selembayung dapat dilihat pada gambar berikut:

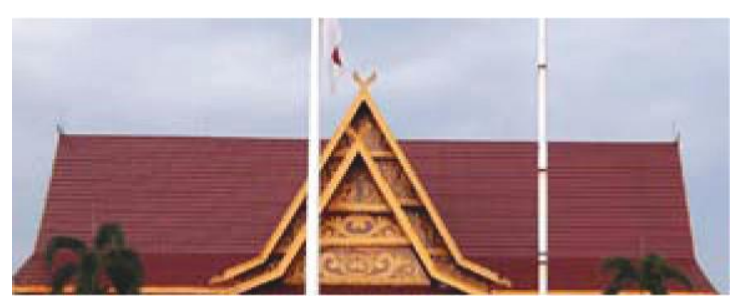

Gambar 4. Selembayung (Dokumentasi Pribadi, 2017)

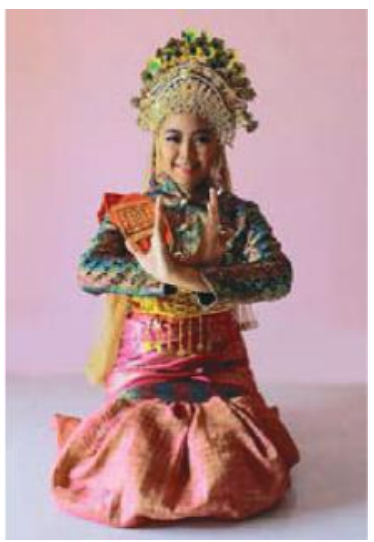

Gambar 5. Gerak Selembayung (Dokumentasi Pribadi, 2017)

Kemudian gerak balam dua sekawan yang merupakan makan kesetiakawanan, persaudaraan, dan juga persahabatan. Gerakan ini mencerminkan bentuk nilai persahabatan. Adapun gerak balam dua sekawan dapat dilihat pada gambar berikut: 


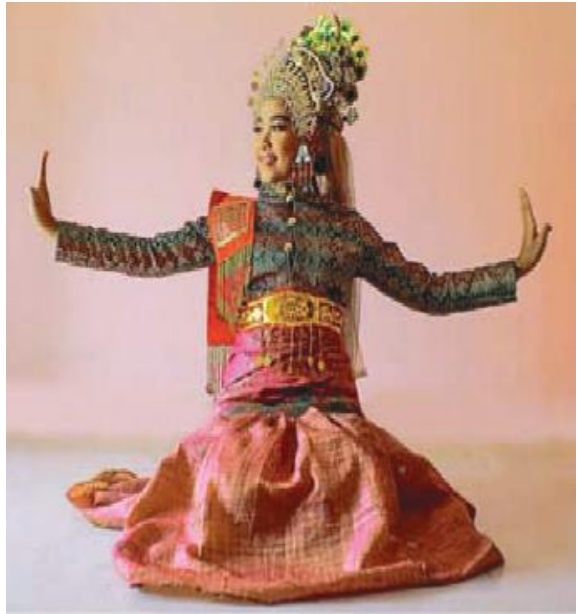

Gambar 6. Gerak Balam Dua Sekawan (Dokumentasi Pribadi, 2017)
Selanjutnya gerak dari aktivitas makan sirih yang merupakan bentuk nilai budaya dari masyarakat Melayu yang mempunyai tradisi memakan sirih dan menggunakan sirih sebagai jamuan kepada tamu. Gerak ini mempunyai bentuk nilai cinta tanah air.

Selain pada gerak, makna filosofi dalam Tari Persembahan juga berasal dari properti nya yaitu tepak sirih yang sarat akan makna terutama pada isi tepak sirih. Adapun makna dalam isi tepak sirih adalah sebagai berikut:

Tabel 1. Makna Isi Tepak Sirih

\begin{tabular}{|c|c|c|}
\hline No. & Nama Isi Tepak Sirih & Makna \\
\hline 1 & Sirih & $\begin{array}{l}\text { Memberi arti sifat yang merendah diri dan senantiasa } \\
\text { memuliakan orang lain, sedangkan dirinya sendiri adalah } \\
\text { bersifat pemberi. }\end{array}$ \\
\hline 2 & Kapur & $\begin{array}{l}\text { Melambangkan hati seseorang yang putih bersih serta } \\
\text { tulus, tetapi jika keadaan tertentu yang memaksanya ia } \\
\text { akan berubah lebih agresif dan marah. }\end{array}$ \\
\hline 3 & Pinang & $\begin{array}{l}\text { Digambarkan sebagai lambang keturunan orang yang } \\
\text { baik budi pekerti, tinggi derajatnya serta jujur. Bersedia } \\
\text { melakukan sesuatu perkara dengan hati terbuka dan } \\
\text { bersungguh-sungguh }\end{array}$ \\
\hline 4 & Tembakau & $\begin{array}{l}\text { Melambangkan hati yang tabah dan bersedia berkorban } \\
\text { dalam segala hal }\end{array}$ \\
\hline 5 & Gambir & $\begin{array}{l}\text { Dengan sifatnya yang kelat kepahit-pahitan melambangkan } \\
\text { kecekalan atau keteguhan hati. }\end{array}$ \\
\hline
\end{tabular}

Selain pada gerak dan properti, makna yang mendalam juga terdapat pada kostum dan proses latihan dari Tari Persembahan. Makna yang terdapat dalam kostum Tari Persembahan merupakan bentuk dari nilai ketaatan atau kereligiusan, nilai cinta tanah air, dan nilai sopan santun. Pada proses latihan Tari Persembahan makna yang terkandung didalamnya adalah bentuk dari nilai kerjasama, kerja keras, dan juga disiplin. Nilai-nilai ini yang membuat Tari Persembahan mempunyai kelebihan yaitu sebagai media ajar dan penanaman karakter bagi masyarakat.
Adapun relevansi makna filosofi terhadap karakter masyarakat Kota Pekanbaru Provinsi Riau yaitu dalam hal filosofi masyarakatnya, yang otomatis merupakan karakter masyarakat itu sendiri. Makna filosofi nilai budaya yang ada dalam masyarakat Melayu ini yang menjadi dasar dalam Tari Persembahan. Selain itu karakter masyarakatnya yang mencerminkan nilai budaya tersebut dapat terlihat dari keseharian masyarakatnya, salah satunya adalah peraturan penggunaan busana Melayu dilingkungan pendidikan, pegawai negeri sipil, dan swasta atau badan usaha daerah. Kemudian contoh lain dari karakter tersebut 
adalah penggunaan huruf Arab Melayu sebagai usaha melestarikan budaya dan kearifan lokal.

\section{KESIMPULAN}

Makna filosofi dari Tari Persembahan berasal dari adab sopan santun masyarakat Melayu yang juga adab tersebut berasal dari filosofi masyarakat Melayu yang berbunyi Adat Bersendikan Syarak Syarak Bersendikan Kitabullah. Adab ini menjadi sumber dari gerak-gerak Tari Persembahan yang berasal dari tradisi menjunjung duli dalam masyarakat Melayu, yaitu tujuannya adalah untuk bersilaturahmi dan menghormati Raja pada hari lebaran idul fitri. Dari tradisi tersebut, kemudian muncul ragam-ragam gerak baru seperti lenggang patah sembilan, memetik bunga, membersihkan sirih, melipat sirih, dan memakan sirih, selembayung, dan balam dua sekawan.

Adapun relevansi dari makna filosofi Tari Persembahan terhadap karakter masyarakat Kota Pekanbaru Provinsi Riau adalah dalam hal filosofi masyarakatnya, yang otomatis merupakan karakter masyarakat itu sendiri. Makna filosofi nilai budaya yang ada dalam masyarakat Melayu ini yang menjadi dasar dalam Tari Persembahan. Selain itu karakter masyarakatnya yang mencerminkan nilai budaya tersebut dapat terlihat dari keseharian masyarakatnya, salah satunya adalah peraturan penggunaan busana Melayu dilingkungan pendidikan, pegawai negeri sipil, dan swasta atau badan usaha daerah. Kemudian contoh lain dari karakter tersebut adalah penggunaan huruf arab Melayu sebagai usaha melestarikan budaya dan kearifan lokal.

\section{DAFTAR PUSTAKA}

Alexander, Jannes. (2016). Filsafat Kebudayaan: Konstruksi Pemikiran Cornelis Anthonie van Peursen dan Catatan Reflektifnya. Yogyakarta. Pustaka Pelajar.

Carroll, Noëll. (1999). Philosophy of Art: A Contemporary Introduction. New York. Routledge.
Gunawan, Heri. (2014). Pendidikan Karaker Konsep dan Implimentasi. Bandung. Alfabeta.

Hadi, S. (2005). Sosiologi Tari. Yogyakarta. Pustaka.

Husin Fazilah \& Jusoh Hj. Adilah. (2016). Makna dan Fungsi Busana dalam Naskah Melayu Syair Agung. Journal of Business and Social Development, 2, 58-75.

Kuswarsantyo. (2008). Pengaruh Sosiokultural Kesenian Tayub Terhadap Perilaku Masyarakat Desa Karangsari Semin Gunungkidul. Laporan penelitian. Jurusan Pendidikan Seni Tari FBS UNY. Yogyakarta.

Koetjaraningrat, dkk. (2016). Masyarakat Melayu dan Budaya Melayu dalam Perubahan. Yogyakarta. Balai Kajian dan Pengembangan Budaya Melayu.

Jamil, O.K Nizami. (2009). Pembakuan Tari Persembahan. Pekanbaru. Lembaga Warisan Budaya Melayu Riau

Luvia, dkk. (200). Makna Filosofi dan Nilainilai yang terkandung dalam Tari Klana Raja Gaya Yogyakarta. PELITA, 3 (1), 3-11.

Royce, P.A. (2007). Antropologi Tari. (Terjemahan F.X Widaryanto). Bandung. Sunan Ambu PRESS STSI.

Ratnaningrum, Ika.(2011). Makna Simbolis dan Peranan Tari Topeng Endel. HARMONIA: Jurnal Pengetahuan dan Pemikiran Seni, 2,125-129.

Sedyawati, Edi, dkk. (1986). Pengetahuan Elemen Tari dan Beberapa Masalah Tari. Jakarta. Direktorat Kesenian Proyek Pengembangan Kesenian Jakarta Departemen Pendidikan dan Kebudayaan.

Suparjo, Paul. (2015). Pendidikan Karakter di Sekolah. Yogyakarta: PT Kanisius.

Svasek, Maruska. (2007). Antrhopology, Art and Cultural Production. London. Pluto Press. 